\title{
Episodic nature of continental arc activity since 750 Ma: a global compilation
}

\author{
Wenrong Cao ${ }^{1}$, Cin-Ty A. Lee ${ }^{1}$, Jade Star Lackey ${ }^{2}$
}

\begin{abstract}
Continental arcs have been recently hypothesized to outflux large amounts of $\mathrm{CO}_{2}$ compared to island arcs so that global flare-ups in continental arc magmatism might drive long-term greenhouse events. Quantitative testing of this hypothesis, however, has been limited by the lack of detailed studies on the spatial distribution of continental arcs through time. Here, we compile a worldwide database of geological maps and associated literature to delineate the surface exposure of granitoid plutons, allowing reconstruction of how the surface area addition rate of granitoids and the length of continental arcs have varied since $750 \mathrm{Ma}$. These results were integrated into an ArcGIS framework and plate reconstruction models. We find that the spatial extent of continental arcs is episodic with time and broadly matches the detrital zircon age record. Most vigorous arc magmatism occurred during the 670-480 Ma and the 250-50 Ma when major greenhouse events are recognized. Low continental arc activity characterized most of the Cryogenian, middle-late Paleozoic, and Cenozoic when climate was cold. Our results indicate that plate tectonics is not steady, with fluctuations in the nature of subduction zones possibly related in time to the assembly and dispersal of continents. Our results corroborate the hypothesis that variations in continental arc activity may play a first order role in driving long-term climate change. The dataset presented here provides a quantitative basis for upscaling continental arc processes to explore their effects on mountain building, climate, and crustal growth on a global scale.
\end{abstract}

Keywords: continental arcs, episodicity, plate tectonics, long-term climate 


\section{Introduction}

Subduction zone volcanism plays an important role in shaping the evolution of Earth's surface. Island arcs, such as the Marianas and Izu-Bonin arcs in the western Pacific, form where an oceanic plate subducts beneath another oceanic plate. Continental arcs, such as the present-day Andes or Cretaceous North American Cordilleran arcs, form when oceanic plates subduct beneath continental plates (Fig. 1a). Because of greater crustal thickness at continental arcs, magmatic differentiation is more extensive in continental arcs than in island arcs, which are thin; continental arcs thus play an important role in the formation of felsic continental crust (e.g. Lee et al, 2007; Lee and Bachman, 2014). The thick crust of continental arcs also results in high elevations, making continental arcs one of the most important environments for mountain building, which in turn influences weathering, atmospheric circulation and the hydrologic cycle (Lee et al., 2015). Continental arcs may also play an important role in long-term climate variability due to the possibility that continental arc volcanoes release more $\mathrm{CO}_{2}$ than island arc volcanoes as a result of magmatic interaction with ancient crustal carbonates stored in the continental upper plate (Fig. 1b) (Lee et al., 2013; Lee and Lackey, 2015; McKenzie et al., 2016).

To what extent the surface geology and environment of Earth is modulated by the rise and fall of continental arcs is uncertain. Has the length of continental arcs varied with time, and if so, what controls the global nature of subduction zones? Attempts have been made to quantify continental arc activity or continental crust formation using large databases of detrital zircon ages (e.g. Voice et al., 2011; Condie and Kröner, 2013; Roberts and Spence, 2015; Paterson and Ducea, 2015). These observations suggest that global continental arc activity is not continuous, but is instead episodic, with recent investigators suggesting a correlation between continental arc activity and greenhouse conditions based solely on detrital zircon data (McKenzie et al., 2016). However, some disadvantages of detrital zircon studies are the lack of the direct geologic context or spatial information of arcs. For these reasons, we present here an independent and more

63 direct constraint on continental arc activity by compiling the distribution of continental

64 arcs through space and time using a worldwide set of geologic maps and related

65 literature. We then synthesize the data with plate reconstruction models to develop a geologic history of continental arcs since the Neoproterozoic. 


\section{Methods}

69

Geologic maps (1:5,000,000 to 1:10,000,000) of Eurasia, North and South America,

71 Africa, Australia, and Antarctica (e.g. Reed et al. 2005; Ren et al., 2013) were used to

72 compile the present-day surface area of felsic-intermediate plutonic rocks (granitoids).

73 We have assumed that felsic magmas, such as granitoids, most likely represent continental arcs for the following reasons. Cawood et al. (2013) suggested that the volumes of subduction-related magmas make up more than $90 \%$ of all volcanism, not including mid-ocean ridge related magmatism. In particular, Lee and Bachmann (2014) showed that felsic (intermediate) magmas are far more abundant in continental arcs than in island arcs, hence we have assumed that the majority of granitoids are formed in the continental arcs. We have, however, excluded the following large plutonic belts where geologic context indicates they are not of continental arc origin: the granitoids associated with the Siberian Traps Large Igneous Province (Ivanov et al., 2013), the A-type granitoids in the Mongolia-Transbaikalian Belt (Jahn et al., 2009), the collision-related Cenozoic granites in the European Alps and Tibet, and the granitic batholiths belonging to the Talkeetna and Kohistan island arc sections (Jagoutz and Kelemen, 2015). Surface areas were extracted using ArcGIS software when shapefiles were available. Otherwise, maps were scanned into high-resolution raster images and processed using ImageJ software (www.imagej.nih.gov). To gauge the productivity of granitoids and continental arc activity, surface area addition rate $\left(\mathrm{km}^{2} / \mathrm{Myr}\right)$ was calculated by dividing the surface area of granitoids generated within a geological interval by the time duration of that interval.

In addition to calculating the surface area addition rate of granitoids, we also reconstructed the linear lengths of continental arcs based on the geology interpreted from literatures as well as the extrapolation between plutonic surface exposures. We then compiled a global history of continental arcs and restored their positions on paleomaps using plate reconstruction models (Scotese, 2016; Li, et al., 2008) in

97 GPlates software (Gurnis et al., 2012). Compiled information on the durations and lengths of continental arcs, error estimate, and a complete list of literature and geologic 


\subsection{Continental arcs through space and time}

The global history of continental arcs is shown in Figure 2 and Figure 3. Two types of continental arcs are differentiated. External arcs (shown as red curves in Fig. 3) are the continental arcs developed along the periphery of a supercontinent. External arcs (shown as purple curves in Fig. 3) are the ones developed internal to an assembling supercontinent, which are usually terminated with continent-continent (or continental terrane) collision. The two types are similar to the classification of accretionary orogen previously proposed (e.g. Murphy et al., 2011).

From 750 Ma to the Early Cryogenian, few continental arcs were active and the

114 length of continental arcs was low (Fig. 3a). From the Late Cryogenian to Late

115 Ediacaran (Fig. 3b), during the final breakup of the Rodinia supercontinent and the

116 formation of the Gondwana supercontinent, Pan-African arcs (e.g. Damara-Kuunga,

117 East African) and the Avalonia-Cadonian arcs became active (e.g. Kröner and Stern,

118 2004; Linnemann et al., 2008). From the Late Ediacaran to Early Cambrian (Fig. 3b-c),

119 coinciding in time with the late stage of the Pan-African arcs, subduction along the

120 Proto-Pacific margin of Gondwana commenced: for example, the Ross arc in

121 Antarctica, the Delamerian arc in Australia, and the Pampeanas-Famatinian arc in

122 South America (Goodge, 2007; Cawood and Buchan, 2007; Rapela et al., 1998).

123 Studies have also suggested that most of the Proto-Tethyan margin of northern

124 Gondwana was active at the same time (Kusky et al., 2003; Zhu et al., 2012).

125 Afterwards, continental arcs waned during the Ordovician and Silurian (Fig. 3d). From 126 the Ordovician to Devonian (Fig. 3d-e), closure of the Iapetus and Rheic Oceans 127 between Baltica, Laurentia, and Gondwana generated the Variscan and Appalachian 128 continental arcs (e.g. Nance and Linnemann, 2008; van Staal et al., 2009). From the 129 Carboniferous to Early Triassic (Fig. 3f-h), diachronous closure of Paleo-Asian oceans, 130 which led to the final assembly of the Pangea supercontinent, gave rise to several 131 Paleo-Asian arcs (e.g. Uralian, Altai, Kazakhstan Balkhash-Yili, Solonker) (e.g. 132 Windley et al., 2007). During the Permian and Early Triassic (Fig. 3g-h), 
133 circum-Pacific subduction commenced along the western and northeastern margins of

134 Pangea, resulting in numerous continental arcs: the western Pacific arcs in Asia, the

135 Cordilleran arcs in North and South America, and the Antarctic Peninsula arc (e.g.

136 Metcalfe, 2011; Dickinson, 2004; Ramos and Kay, 1992). During the

137 Mesozoic-Paleocene (Fig. 3h-j), these circum-Pacific arcs dominated global

138 continental arc activity, reaching their longest extents in the Late Cretaceous. Several

139 Tethyan arcs were also active during the same period (e.g. Yin and Harrison, 2000). In

140 the Cenozoic (Fig. 3k-1), the Gangdese and Iran-Turkey arcs shut down with the

141 progressive closure of the Neo-Tethyan Ocean from the Himalaya to the Caucasus (Zhu

142 et al., 2015; Yin, 2010). Many of the circum-Pacific continental arcs also terminated in

143 the Cenozoic. Trench retreat resulted in western Pacific continental arcs transitioning

144 into island arc systems (e.g., Marianas, Izu-Bonin) (Ishizuka et al., 2014). Arc

145 volcanism in western North America waned due to the onset of the flat subduction and

146 collision of the Pacific-Farallon ridge (Dickinson, 2004).

Figure 4(a-d) summaries geological events and the compiled results of this study.

149 There are two periods of time since $750 \mathrm{Ma}$ when the lengths of continental arcs were

150 high (Fig. 4d). The first period is during the Late Cryogenian and Cambrian ( 670-480

151 Ma), defined by the Pan-African and peri-Gondwana continental arcs. The second

152 period was in the Mesozoic-early Paleogene ( 250-50 Ma), defined by the Paleo-Asian

153 arcs, Tethyan arcs, and circum-Pacific continental arcs. The global lengths of

154 continental arcs were low from the Late Tonian to Early Cryogenian (750 Ma-680 Ma),

155 during most of the Paleozoic ( 470-250 Ma), and during much of the Cenozoic ( $\sim 50-0$

$156 \mathrm{Ma})$. The lengths of continental arcs during the two peak periods were up to about 1.5 to

1572.5 times as long as the present-day length. In contrast, the lengths of continental arcs

158 during most of the low periods are comparable to or lower than the present-day length.

\subsection{Surface area addition rates}

In the Phanerozoic, the global surface area addition rate of granitoids shows 163 several peaks and lows (Fig. 4b). Major peaks appear in the Permian-Triassic and

164 during the Late Jurassic to Paleocene. Lows characterize the Early to Middle Paleozoic, 165 Middle Triassic-Early Jurassic, and most of the Cenozoic. In the Paleozoic, the global 
surface area addition rate is mainly composed of continental arcs in Eurasia. In the

167 Mesozoic, the importance of continental arcs in North and Central America increased

168 while continental arcs in Eurasia waned. In the Cenozoic, surface area addition rates

169 decreased in North and Central America and Eurasia. We omitted Neoproterozoic rates

170 because the age resolution of Precambrian rocks in geologic maps is too coarse for any

171 meaningful calculation.

Surface area addition rates, however, are undoubtedly subject to sampling bias

174 associated with erosional and tectonic preservation and, to a lesser extent, sedimentary 175 cover. There is no sure way to correct for these sampling biases, but if we assume that 176 older plutons are statistically more under-represented due to erosion, we can make 177 some hypothetical corrections for such loss. For example, Fig. 4c shows a scenario in 178 which we assume the probability of preservation decays exponentially with time with 179 different half-lives tested (details and other types of corrections are shown in the 180 Supplementary Materials, Fig. S1). Compensating for possible erosional bias enhances 181 the peaks in the early Paleozoic and Permian-Triassic and the minima from the 182 Devonian to Early Permian (Fig. 4c).

\section{Discussion}

\subsection{Comparisons between continental arc datasets}

188 Comparison between the corrected surface area addition rate and the length of 189 continental arcs (Fig. 4c, d) shows that the patterns of the two datasets are broadly 190 similar since the Silurian: both show peaks in the Permian-Triassic and 191 Jurassic-Paleocene. Minimums in the Devonian-Early Permian and middle-late 192 Cenozoic also largely match. Dissimilarities between the two datasets can be seen 193 during the Precambrian and early Paleozoic. These dissimilarities are caused by the 194 lack of age resolution on Precambrian plutons in geologic maps and erosional/burial 195 bias. For example, calculated Cambrian surface area addition rate is underestimated 196 because of ice covering the Transantarctic Mountains (Cambrian Ross continental arc). 197 Arc length better captures the true extent of continental arcs. 
We can now compare our results to the global detrital zircon database compiled by

200 Voice et al. (2010). Encouragingly, detrital zircon ages show peaks and troughs, which

201 broadly match those defined by surface area addition rate and length of continental arcs

202 (Fig. 4d, e). There is debate on whether detrital zircon ages reflect the actual episodic

203 nature of magmatic processes (e.g. Condie, 2005; O’Neill et al., 2015) or reflect

204 preservational bias, specifically preservation during collisional orogenies (Cawood et

205 al., 2013). We suggest that preservational bias is probably not the dominant factor in

206 controlling detrital age histograms. In Fig. 4e, it can be seen that the detrital zircon age

207 pattern does not clearly correlate with supercontinent assembly. Instead, it can be seen

208 that the surface area addition rate of granitoids, length of continental arcs, and the

209 global detrital zircon U/Pb ages (including those of McKenzie et al., 2016) appear to be

210 correlated. We thus argue that the patterns of global detrital zircon ages together with

211 the surface area addition rate of granitoids and the length of continental arcs reflect the

212 real episodic nature of continental arc activity.

\section{$214 \quad 4.2$ The episodicity of continental arcs}

The broad agreement between surface area addition rate of granitoids, length of

217 continental arcs, and the global detrital zircon record indicates that continental arc

218 activity since $750 \mathrm{Ma}$ has not been constant. Global continental arc activity peaked

219 twice during this time: once from 670-480 Ma and again from 250-50 Ma. In particular,

220 these periods of enhanced continental arc activity each lasted for $200 \mathrm{My}$. Our

221 observations indicate that although plate tectonics has been continuous since at least

$222750 \mathrm{Ma}$, the nature and tempo of plate tectonics may vary on $200 \mathrm{My}$ timescales.

223 Combined with the well-known observation that oceanic crust production rates are also

224 not constant (e.g. Becker et al., 2009; van Der Meer et al., 2014), our observations of

225 changes in the nature of subduction zones suggest that plate tectonics is fundamentally

226 non-steady.

227 Some insight can be gained by examining when continental arcs were at their peak.

228 Both periods were associated with the assembly of continents. The 670-480 Ma

229 flare-up was associated with assembly of the Gondwana supercontinent during which

230 the continental arcs internal to the supercontinent (Pan-African arcs) overlapped in time

231 with the continental arcs external to the supercontinent (peri-Gondwana arcs). The 
250-50 Ma flare-up was associated with the assembly and dispersal of the Pangean supercontinent. The Paleo-Asian and Tethyan arcs, which were internal to Pangea when it assembled, coincided in time with the circum-Pacific arcs along the periphery of the supercontinent, which continued during its dispersal. Cawood and Buchan (2007) suggested that the final assembly of a supercontinent is synchronous with subduction initiation and accretionary orogens along the margins of the supercontinent. Our compilation supports this observation.

What seems clear is that the nature of subduction zones varies systematically with time, probably influenced by the assembly and dispersal of continents. The geodynamics causing the episodicity might be tied to episodic mantle processes, including convection and mantle plumes (Anderson, 1982; Gurnis, 1988). In particular, it has been suggested that during a supercontinent interval, a strong temperature gradient develops beneath the oceanic domain and the supercontinent domain due to more efficient convective loss of heat from the oceanic domain and the inefficient heat loss through the stagnant continental domain; this temperature difference generates lateral pressure gradients that lead to the break-up of supercontinents, during which the leading edge of dispersing continents are put into compression, which favors the development of continental arcs (Gurnis, 1988; Lenardic et al., 2011; Lee et al., 2013). Whether changes in continental arc length correlate with changes in total length of arcs is unclear, but could be a fruitful area of future research. Recently, van der Meer et al. (2014) used seismic tomography of subducted oceanic slabs to constrain the length of global subduction zones since $250 \mathrm{Ma}$. They found that during the Middle-Late Jurassic the total length of subduction zones was twice as long as today. Using our constraints on the length of continental arcs, we estimate that continental arcs made up 40-50\% of global subduction zones during the Jurassic and Cretaceous and $~ 30 \%$ today. This suggests that the greater length of continental arcs in the Jurassic and Cretaceous could in part be due to a greater length of subduction zones.

\subsection{Implications for long-term climate and continental crust growth}

In the past $750 \mathrm{My}$, Earth's climate has switched back and forth between several major icehouse and greenhouse events. Distinctive glaciation events have occurred in the late 
265 Neoproterozoic between 770-635 Ma (Allen and Etienne, 2008). Notable ones such as

266 the Cryogenian Sturtian (716 Ma) and Marinoan (635 Ma) glaciations reached

267 low-latitudes (e.g. Pierrehumbert et al., 2011). Paleozoic major glaciations occurred at

$268 \sim 445$ Ma during the Himantian (Finnegan et al., 2011) and 340-260 Ma during the

269 Late Paleozoic (Montañez and Poulsen, 2013). Global cooling in the Cenozoic started

270 around $50 \mathrm{Ma}$ and ice sheets started to form in Antarctica by $34 \mathrm{Ma}$ (Zachos et al.,

271 2001). In between these icehouse events, major greenhouse events occurred in the Late

272 Ediacaran-Early Paleozoic (560-470 Ma) (e.g. Berner and Kothavala, 2001) and from

273 the Triassic to the Eocene (250-34 Ma) (e.g. Berner and Kothavala, 2001; Zachos et al.,

274 2001). Our study shows that the late Neoproterozoic, Middle-Late Paleozoic and Late

275 Cenozoic icehouse events largely match the periods of low continental arc activity. In

276 contrast, the Cambrian, Mesozoic-Eocene greenhouse events largely match the periods

277 of high continental arc activity (Fig. 4a, c, d). This observation supports the hypothesis

278 that that continental arcs help drive greenhouse events (Lee et al., 2013; Lee and

279 Lackey, 2015), which is also supported by independent study using detrital zircon

280 age-derived proxies by McKenzie et al. (2014, 2016). To further quantitatively test the 281 hypothesis, constraints on the $\mathrm{CO}_{2}$ concentration in arc magmas (e.g. Wallace, 2005),

282 spatial relationships between magmas and carbonate wallrocks, and the efficiency of

283 decarbonation (e.g. Carter and Dasgupta, 2016) will be needed. We also note that

284 uplifted juvenile crustal materials in continental arcs can be chemically weathered,

285 consuming $\mathrm{CO}_{2}$ for tens of million years after arc termination (Lee et al., 2015). Thus,

286 arc remnants after global flare-ups could act as strong $\mathrm{CO}_{2}$ sinks promoting global

287 cooling and even the switch to ice house conditions (Lee et al., 2015). Both roles of

288 continental arcs in modulating paleo-climate should be quantitatively evaluated and

289 incorporated into current long-term carbon-cycle models, such as the GEOCARB (e.g.

290 Berner and Kothavala, 2001). Finally, we note that Large Igneous Province (LIP)

291 events were more active in the Mesozoic, especially in the Cretaceous (Kidder and

292 Worsley, 2001). Whether there is a genetic link between continental arc flare-up and

293 frequent LIP events is unclear, but such LIPs, superimposed on a greenhouse baseline,

294 could lead to mid-Cretaceous hothouse excursions.

\section{Conclusions}


298 We show that the global continental arc activity has fluctuated, at least as far back as

$299750 \mathrm{Ma}$. Continental arc activity was highest during the late Cryogenian-Cambrian and

300 the Mesozoic-Early Paleogene, but low during most of the Cryogenian, middle-late

301 Paleozoic, and Cenozoic. Continental arc activity is related to the assembly and

302 dispersal of continents. More continental arcs are generated during the final assembly

303 of a supercontinent when internal-type continental arcs overlapped in time with the

304 external-type continental arcs, and the continental arcs of the latter type could continue

305 to exit during the breakup of supercontinent. Strong and weak periods of continental arc

306 activity largely match the major warm and cold periods, respectively, since $750 \mathrm{Ma}$.

307 This suggests that continental arcs may drive greenhouse conditions by amplifying

308 volcanic $\mathrm{CO}_{2}$ degassing, and when continental arc activity subsides, climate reverts

309 back to an icehouse baseline. Our compilation provides a basis to incorporate the

310 effects of continental arcs into global models on mountain building, paleo-climate, and

311 continental crust growth.

\section{Acknowledgements}

This study was funded by a United States National Science Foundation (OCE-1338842)

316 awarded to Lee and represents a contribution from the Continental-Island Arc (CIA)

317 group at Rice University (www.arc2climate.org). A.W. Bally is thanked for his advice

318 and help on preparing and interpreting geological maps and informal review. Peter

319 Cawood and Brenhin Keller are thanked for their constructive review comments.

\section{FIGURE CAPTIONS}

Fig. 1 (a) Cartoon of island and continental arcs; (b) A continental arc showing how the interaction of magmas with carbonates in the upper plate can enhance $\mathrm{CO}_{2}$ degassing.

Fig. 2 Global history of continental arcs since $750 \mathrm{Ma}$. Continental arcs are named using their counterpart orogens or geographic locations. Small red vertical bars indicate that a continental arc terminated with continent-continent (or continental terrane) collision. The thicknesses of the bars approximately represent their lengths. Cam, Cambrian; O, Ordovician; S, Silurian; D, Devonian; C, Carboniferous; P, Permian; T, 
Triassic; J, Jurassic; K, Cretaceous; Pg, Paleogene; Ng, Neogene.

333 Fig. 3 Spatiotemporal distributions of continental arcs on a series of paleomaps

334 (Mollweide projection) (a to 1). Red and purple curves represent external and internal 335 continental arcs, respectively. Gray represents landmass. Abbreviations of continental 336 arcs: AC, Avalonia-Cadomian; Ak, Alaska; Alt, Altai; And, Andes; Ant, Antarctic 337 Peninsula; App, Appalachian; Atc, continental arcs in the Arctic region. Bsl, Brasiliano,

338 CA, Central America; Cas, Cascade; Chi, Chilenia; Del, Delamerian; DK,

339 Damara-Kuunga; EA, East African, Fam, Famatinian; Gd, Gangdese; GTM,

340 Gondwana Proto-Tethyan margin; ICS, Indochina-Sumatra; IT, Iran-Turkey; JK,

341 Jiangda-Hoh Xil Shan-Karakorum; Kam, Kamchatka; Kaz, Kazakhstan Balkhash-Yili;

342 Kun; Kunlun; Lan, Lachlan; MB, Marie Byrd Land; MO, Mongol-Okhotsk; NA,

343 North American Cordilleran; NE, New England; NZ, New Zealand; OC,

344 Okhotsk-Chukotka; Pam, Pampeanas; Pe, Peru; Qin, Qinling; Ros, Ross; SA, South

345 American Cordilleran; Sal, Saldanian; Sma, Sumatra; Sol, Solonker; Tim, Timanide;

346 TS, Trans-Sahara, TSS, Tian Shan-Solonker; Ula, Uralian; Var, Variscan; Vk,

347 Verkhoyansk; WP, West Pacific. Plate reconstructions based on Scotese (2016) and Li 348 et al. (2008).

Fig. 4 Summary plot showing (a) Supercontinent events, dominant continental arcs, greenhouse-icehouse events, and surface areas of Large Igneous Provinces (LIPs, Kidder and Worsley, 2010). OJ, Ontong Java, Kerg., Kerguelen; (b) Global and regional surface area addition rates of granitoids; (c) Global surface area addition rate of granitoids after applying different compensation models; (d) Length estimates of continental arcs. Maximum length is based on geological interpretations from literatures. Minimum length of Phanerozoic arcs is largely based on surface exposures of granitoids on maps. Minimum lengths of Proterozoic arcs are assigned to half of their maximum lengths due to low spatial and temporal resolutions of Proterozoic plutons on

360 of global detrital zircon ages from Voice et al. (2010). Cam, Cambrian; O, Ordovician;

361 S, Silurian; D, Devonian; C, Carboniferous; P, Permian; T, Triassic; J, Jurassic; K,

362 Cretaceous; Pg, Paleogene; Ng, Neogene; Pz, Paleozoic; Mz, Mesozoic; Cz, Cenozoic. 


\section{References}

365 Anderson, D. L., 1982. Hotspots, polar wander, Mesozoic convection and the geoid. Nature 297, 391-393.

Allen, P. A., Etienne, J. L., 2008. Sedimentary challenge to snowball Earth. Nature Geoscience 1, 817-825.

Becker, T. W., Conrad, C. P., Buffett, B., Müller, R. D., 2009. Past and present seafloor age distributions and the temporal evolution of plate tectonic heat transport. Earth and Planetary Science Letters 278, 233-242.

Berner, R. A., Kothavala, Z., 2001. GEOCARB III: A revised model of atmospheric $\mathrm{CO}_{2}$ over phanerozoic time. Am. J. Sci. 301, 182-204.

Carter, L. B., Dasgupta, R., 2016. Effect of melt composition on crustal carbonate assimilation - Implications for the transition from calcite consumption to skarnification and associated $\mathrm{CO}_{2}$ degassing. Geochemistry, Geophysics, Geosystems 17.

Cawood, P. A., Buchan, C., 2007. Linking accretionary orogenesis with supercontinent assembly. Earth-Science Reviews 82, 217-256.

Cawood, P. A., Hawkesworth, C. J., Dhuime, B., 2013. The continental record and the generation of continental crust. Geological Society of America Bulletin 125, 14-32.

Condie, K, C., 2005. Earth as an evolving planetary system. Elsevier Academic Press, Burlington, MA, USA.

Condie, K. C., Kröner, A., 2013. The building blocks of continental crust: Evidence for a major change in the tectonic setting of continental growth at the end of the Archean. Gondwana Research 23, 394-402.

Dickinson, W. R., 2004. Evolution of the North American cordillera. Annu. Rev. Earth Planet. Sci. 32, 13-45.

Finnegan, S., Bergmann K., Eiler, J. M., Jones, D. S., Fike, D. A., Eisenman, I., Hughes, N. C., Tripati, A. K., Fischer, W. W., 2011. The magnitude and duration of Late Ordovician-Early Silurian glaciation. Science 331, 903-906.

Goodge, J. W., 2007. Metamorphism in the Ross orogen and its bearing on Gondwana margin tectonics. Geological Society of America Special Papers 419, 185-203. supercontinents. Nature 332, 695-699. 
Gurnis, M., Turner, M., Zahirovic, S., DiCaprio, L., Spasojevic, S., Müller, R. D., Boyden, J., Seton, M., Manea, V. C., Bower, D. J., 2012. Plate tectonic reconstructions with continuously closing plates. Computers and Geosciences 38, $35-42$.

Ishizuka O, Tani, K, Reagan M. K., 2014. Izu-Bonin-Mariana forearc crust as a modern ophiolite analogue. Elements 10, 115-120.

Ivanov, A. V., He, H., Yan, L., Ryabov, V. V., Shevko, A. Y., Palesskii, S. V., Nikolaeva, I. V., 2013. Siberian Traps large igneous province: Evidence for two flood basalt pulses around the Permo-Triassic boundary and in the Middle Triassic, and contemporaneous granitic magmatism. Earth-Science Reviews 122, 58-76.

Jagoutz, O., Kelemen, P. B., 2015. Role of Arc Processes in the Formation of Continental Crust. Annual Review of Earth and Planetary Sciences 43, 363-404.

Jahn, B. M., Litvinovsky, B. A., Zanvilevich, A. N., Reichow, M., 2009. Peralkaline granitoid magmatism in the Mongolian-Transbaikalian Belt: Evolution, petrogenesis and tectonic significance. Lithos 113, 521-539.

Kidder, D. L., Worsley, T. R., 2010. Phanerozoic Large Igneous Provinces (LIPs), HEATT (Haline Euxinic Acidic Thermal Transgression) episodes, and mass extinctions. Palaeogeography, Palaeoclimatology, Palaeoecology, 295, 162-191.

Kröner, A., Stern, R. J., 2004. Africa: Pan-African orogeny. Encyclopedia of Geology. Elsevier, 1-12.

Kusky, T. M., Abdelsalam, M., Tucker, R. D., Stern, R. J., 2003. Evolution of the East African and related orogens, and the assembly of Gondwana. Precambrian Research 123, 81-85.

Lee, C.-T. A., Bachmann, O., 2014. How important is the role of crystal fractionation in making intermediate magmas? Insights from $\mathrm{Zr}$ and $\mathrm{P}$ systematics, Earth Planet Sci. Letters 393, 266-274.

Lee, C-T. A., Lackey, J. S., 2015. Arc magmatism, crustal carbonates, and long-term climate variability. Elements 11, 125-130.

Lee, C.-T. A., Shen, B., Slotnick, B. S., Liao, K., Dickens, G. R., Yokoyama, Y., Lenardic, A., Dasgupta, R., Jellinek, M., Lackey, J. S., Schneider, T., Tice, M. M., 2013. Continental arc-island arc fluctuations, growth of crustal carbonates, and long-term climate change. Geosphere 9, 21-36.

Lee, C.-T. A., Morton, D. M., Kistler, R. W., Baird, A. K., 2007. Petrology and 
tectonics of Phanerozoic continent formation: from island arcs to accretion and continental arc magmatism. Earth Planet. Sci. Lett. 263: 370-387.

Lee, C.-T. A., Thurner, S., Paterson, S., Cao, W., 2015. The rise and fall of continental arcs: Interplays between magmatism, uplift, weathering, and climate. Earth and Planetary Science Letters 425, 105-119.

Lenardic, A., Moresi, L., Jellinek, A.M., O’Neill, C.J., Cooper, C.M., and Lee, C.T., 2011. Continents, super- continents, mantle thermal mixing, and mantle thermal isolation: Theory, numerical simulations, and laboratory experiments: Geochemistry Geophysics Geosystems, v. 12, Q10016.

Li, Z. X., Bogdanova, S. V., Collins, A. S., Davidson, A., De Waele, B., Ernst, R. E., Fitzsimons, I. C. W., Fuck, R. A., Gladkochub, D. P., Jacobs, J., Karlstrom, K. E., 2008. Assembly, configuration, and break-up history of Rodinia: a synthesis. Precambrian research 160, 179-210.

Linnemann, U., Pereira, F., Jeffries, T. E., Drost, K., Gerdes, A., 2008. The Cadomian Orogeny and the opening of the Rheic Ocean: The diacrony of geotectonic processes constrained by LA-ICP-MS U-Pb zircon dating (Ossa-Morena and Saxo-Thuringian Zones, Iberian and Bohemian Massifs). Tectonophysics 461, 21-43.

McKenzie, N. R., Hughes, N. C., Gill, B. C., Myrow, P. M., 2014. Plate tectonic influences on Neoproterozoic-early Paleozoic climate and animal evolution. Geology 42, 127- 130.

McKenzie, N. R., Horton, B. K., Loomis, S. E., Stockli, D. F., Planavsky, N. J., Lee, C. -T. A., 2016. Continental arc volcanism as the principal driver of icehouse-greenhouse variability. Science 352, 444-447.

Metcalfe, I., 2011. Tectonic framework and Phanerozoic evolution of Sundaland.

Montañez, I. P., Poulsen, C. J., 2013. The Late Paleozoic ice age: an evolving paradigm. Annual Review of Earth and Planetary Sciences 41, 629-656.

Murphy, J. B., van Staal, C. R., Collins, W. J., 2011. A comparison of the evolution of

461 Nance, R. D., Linnemann, U., 2008. The Rheic Ocean: Origin, Evolution, and Significance. GSA Today 18, 4-9. 
O'Neill, C., Lenardic, A., Condie, K. C., 2015. Earth's punctuated tectonic evolution: cause and effect. Geological Society, London, Special Publication 389, 17-40.

Paterson, S. R., Ducea, M. N., 2015. Arc magmatic tempos: gathering the evidence. Elements 11, 91-98.

Pierrehumbert, R. T., Abbot, D. S., Voigt, A., Koll, D., 2011. Climate of the Neoproterozoic. Annu. Rev. Earth Planet. Sci. 39, 417-460.

Ramos, V. A., Kay, S. M., 2006. Overview of the tectonic evolution of the southern Central Andes of Mendoza and Neuquén ( $35^{\circ}-39^{\circ} \mathrm{S}$ latitude). Geological Society of America Special Paper 407: Evolution of an Andean Margin: A Tectonic and Magmatic View from the Andes to the Neuquén Basin $\left(35^{\circ}-39^{\circ} \mathrm{S}\right.$ lat) (Vol. 407, pp. $1-17)$.

Rapela, C. W., Pankhurst, R. J., Casquet, C., Baldo, E., Saavedra, J., Galindo, C., 1998. Early evolution of the Proto-Andean margin of South America. Geology 26, 707-710.

Reed, J.C., Jr., Wheeler, J.O., Tucholke, B.E., 2005. Geologic Map of North America-Perspectives and explanation: Boulder, Colorado, Geological Society of America, Decade of North American Geology 1-28.

Ren, J., Niu, B., Wang, J., Jin, X., Zhao, L., Liu, R., 2013. Advances in research of Asian geology_A summary of 1: 5M International Geological Map of Asia project. Journal of Asian Earth Sciences 72, 3-11.

Roberts, N. M. W., Spencer, C. J. 2015. The zircon archive of continent formation through time. Geological Society, London, Special Publications 389, 197-225.

Scotese, C.R., 2016. PALEOMAP PaleoAtlas for GPlates and the PaleoDataPlotter Program, Geological Society of America, North-Central Section, 50th Annual Meeting, (April 18-19, 2016), University of Illinois, Champaign-Urbana, IL, DOI: 10.1130/abs/2016NC-275387.

van Staal, C. R., Whalen, J. B., Valverde-Vaquero, P., Zagorevski, A., Rogers, N., 2009. Pre-Carboniferous, episodic accretion-related, orogenesis along the Laurentian margin of the northern Appalachians. Geological Society, London, Special Publications 327, 271-316.

van Der Meer, D. G., Zeebe, R. E., van Hinsbergen, D. J. J., Sluijs, A., Spakman, W., Torsvik, T. H., 2014. Plate tectonic controls on atmospheric $\mathrm{CO}_{2}$ levels since the Triassic. Proceedings of the National Academy of Sciences 111, 4380-4385. 
Voice, P. J., Kowalewski, M., Eriksson, K. A., 2011. Quantifying the Timing and Rate of Crustal Evolution: Global Compilation of Radiometrically Dated Detrital Zircon Grains. The Journal of Geology 119, 109-126.

Wallace, P.J., 2005. Volatiles in subduction zone magmas: Concentrations and fluxes based on melt inclusion and volcanic gas data: Journal of Volcanology and Geothermal Research 140, 217-240.

Windley, B. F., Alexeiev, D., Xiao, W., Kröner, A., Badarch, G., 2007. Tectonic models for accretion of the Central Asian Orogenic Belt. Journal of the Geological Society $164,31-47$.

Yin, A., Harrison, T. M., 2000. Geologic evolution of the Himalayan-Tibetan orogen. Annual Review of Earth and Planetary Sciences 28, 211-280.

Yin, A., 2010. Cenozoic tectonic evolution of Asia: A preliminary synthesis. Tectonophysics 488, 293-325.

Zachos, J., Pagani, M., Sloan, L. Thomas, E., Billups, K., 2001. Trends, rhythms, and aberrations in global climate 65 Ma to present, Science 292, 686-693.

Zhu, D.-C., Wang, Q., Zhao, Z.-D., Chung, S.-L., Cawood, P. A., Niu, Y., Liu, S.-A., Wu, F.-Y. Mo, X.-X., 2015. Magmatic record of India-Asia collision. Scientific reports 5:14289. 


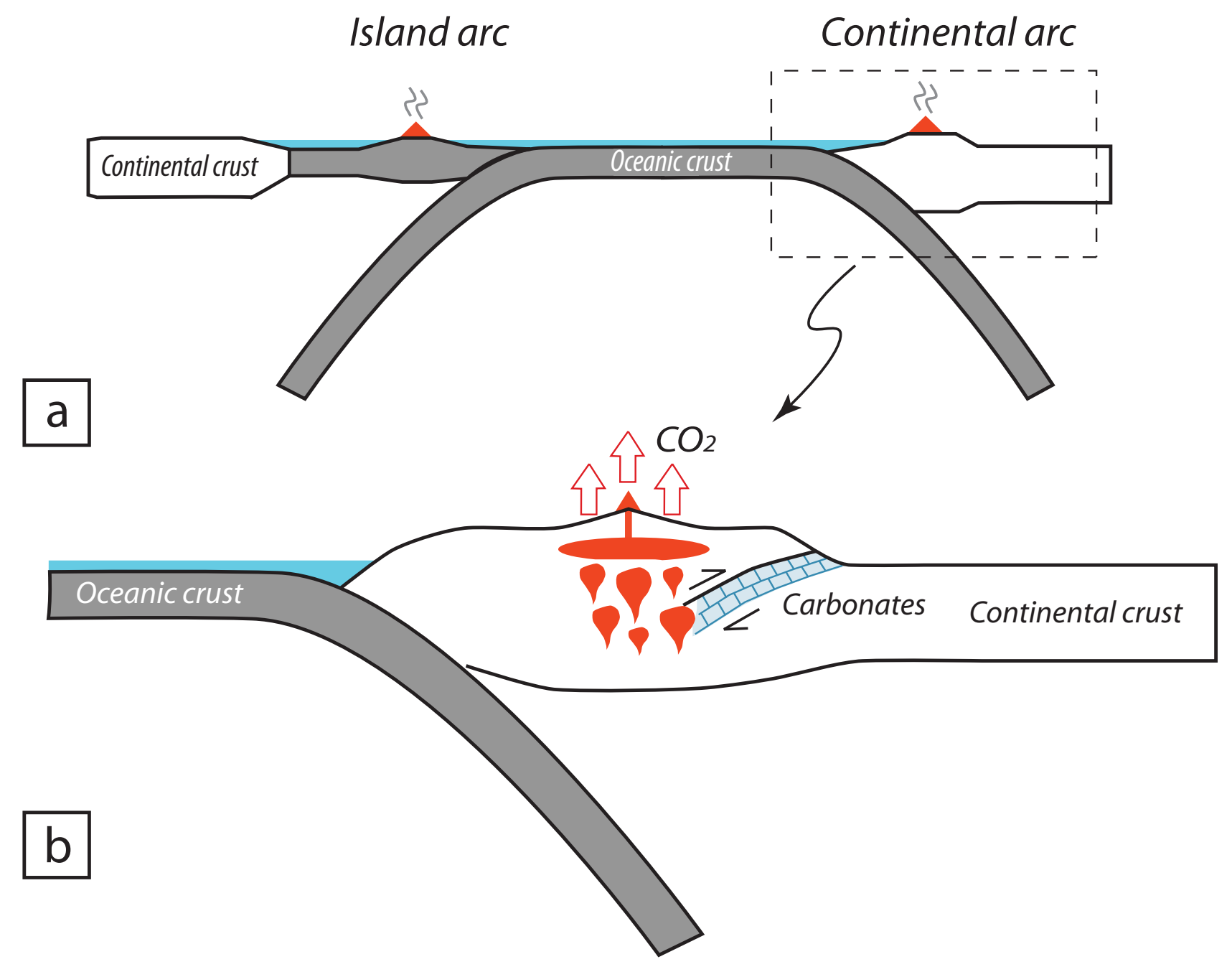

Fig. 1 


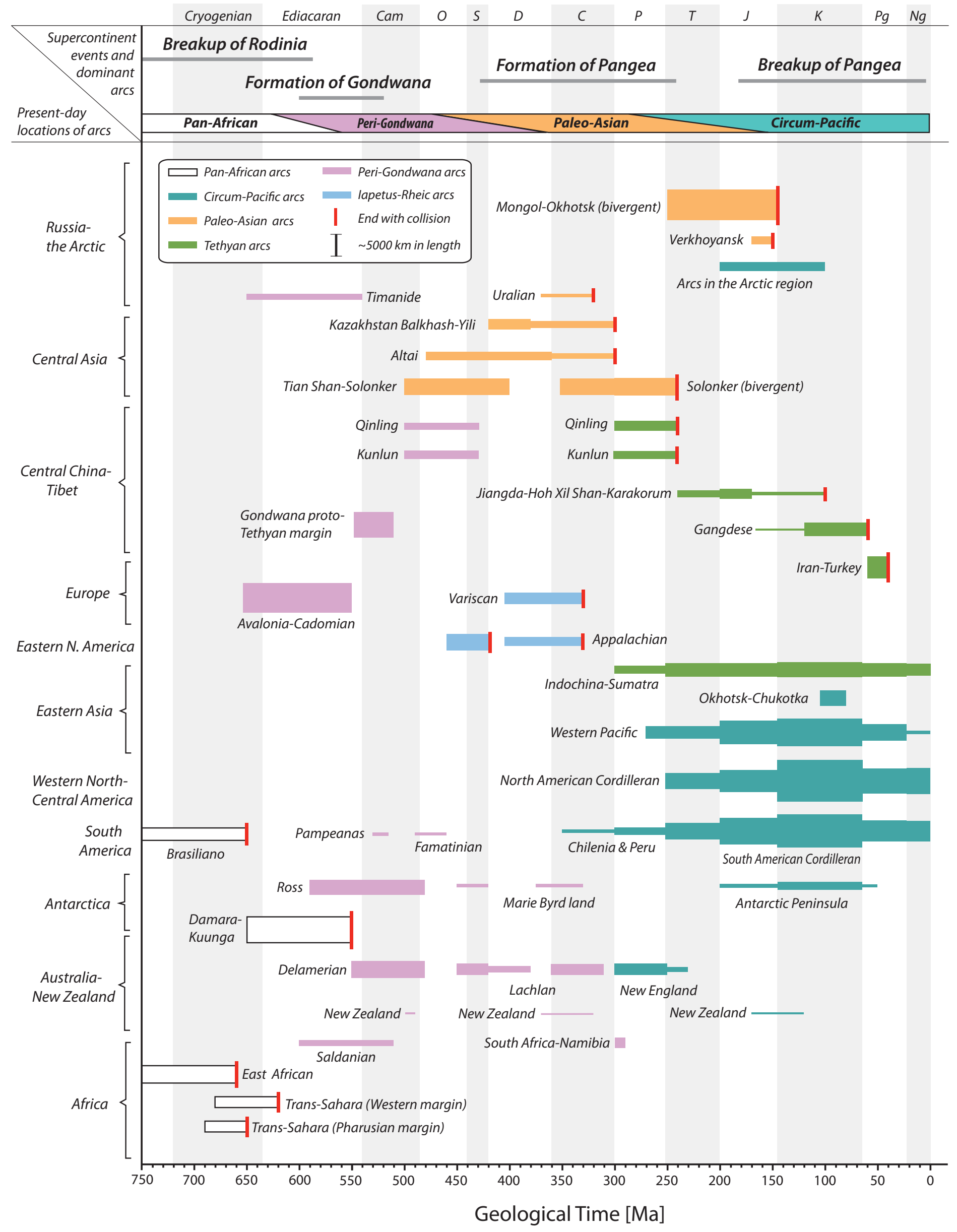

Fig. 2 


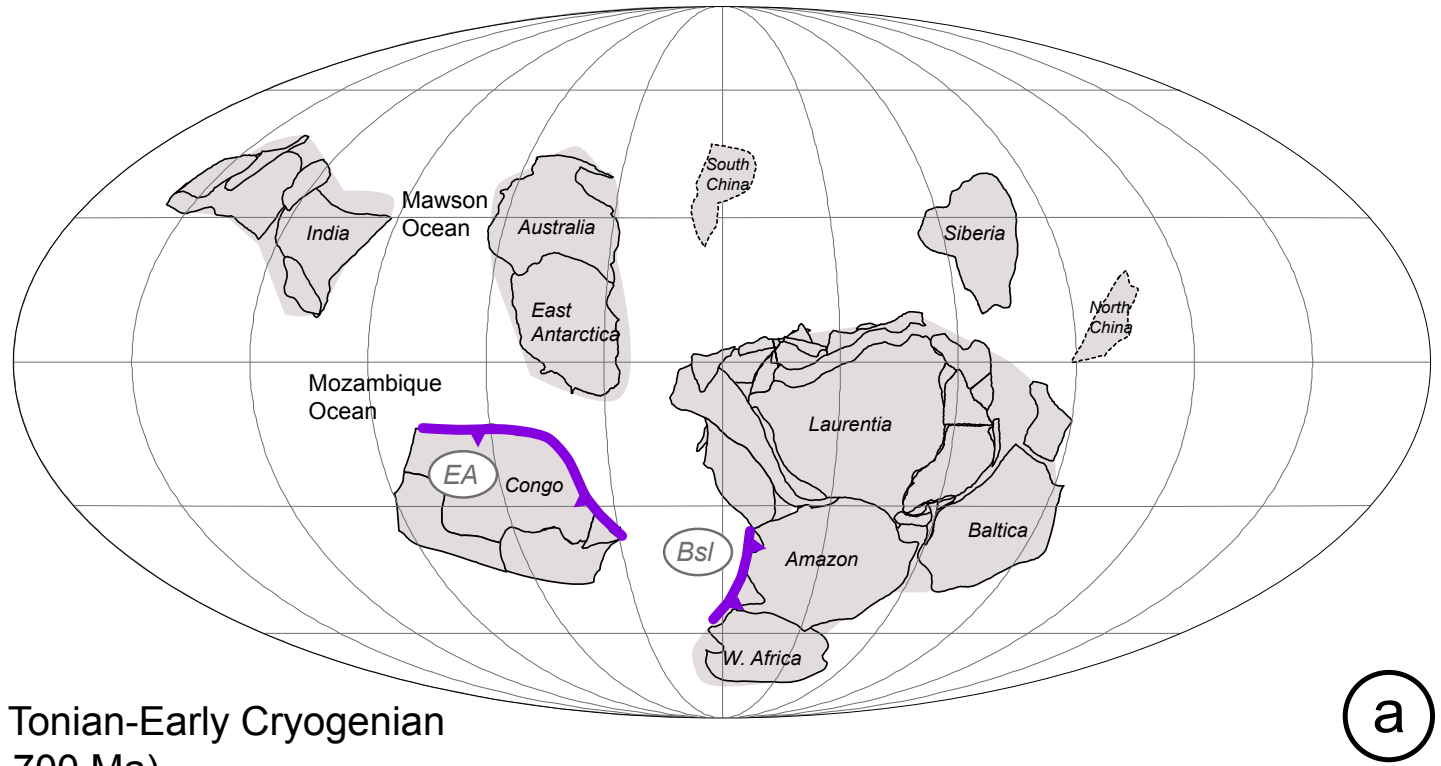

(750-700 Ma)

Central Meridian: $180^{\circ}$

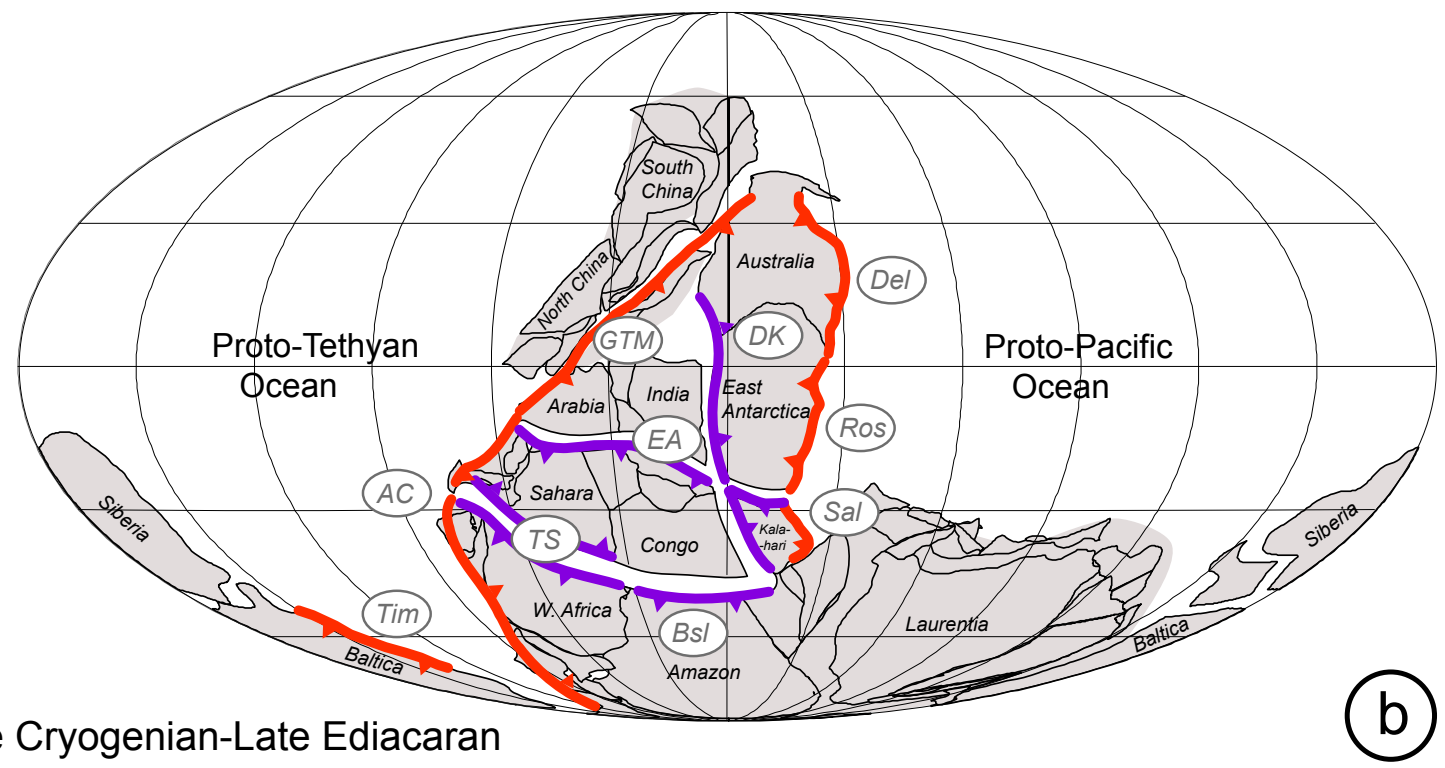

(660-570 Ma)

Central Meridian: $180^{\circ}$

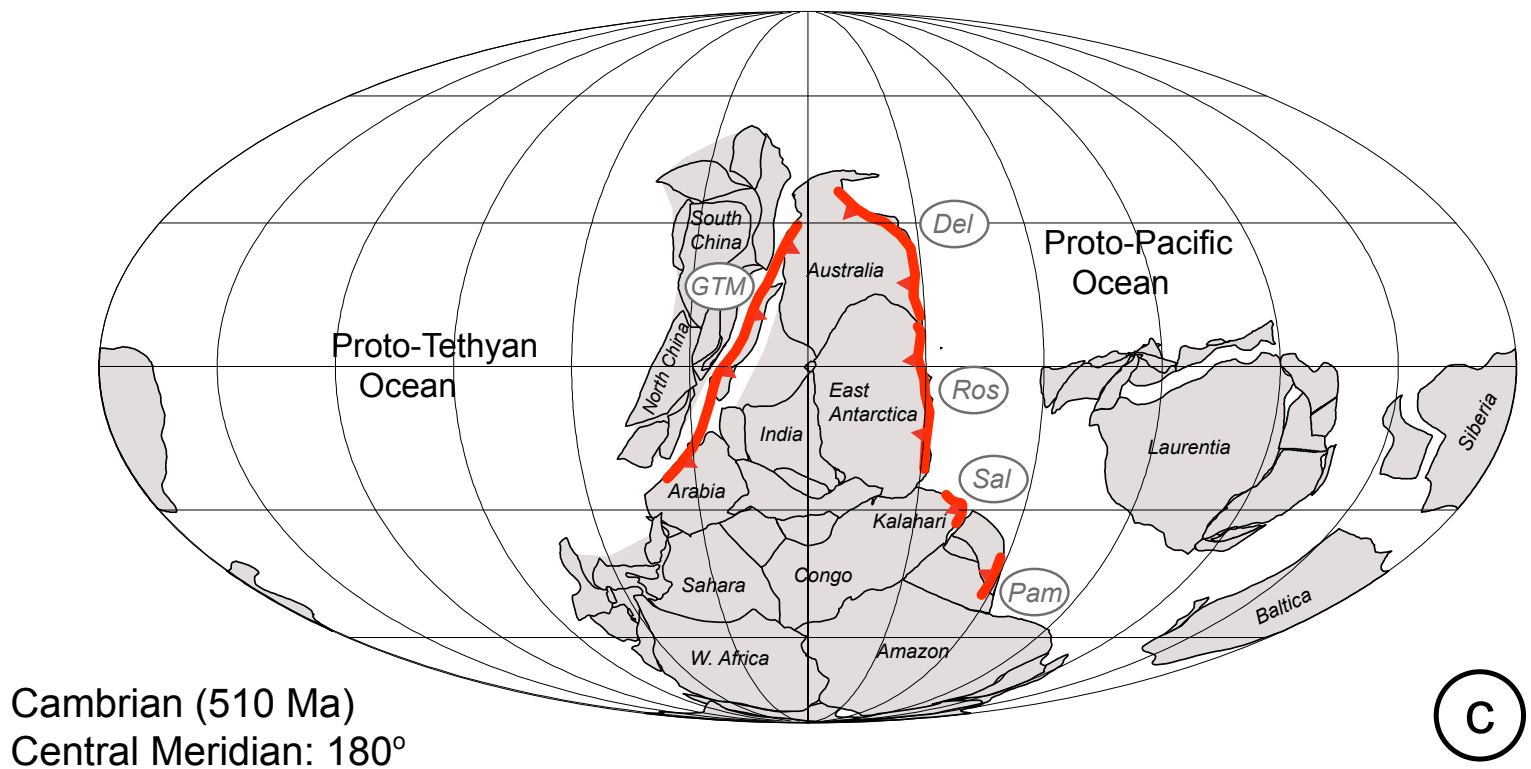

Fig. 3 a-c 


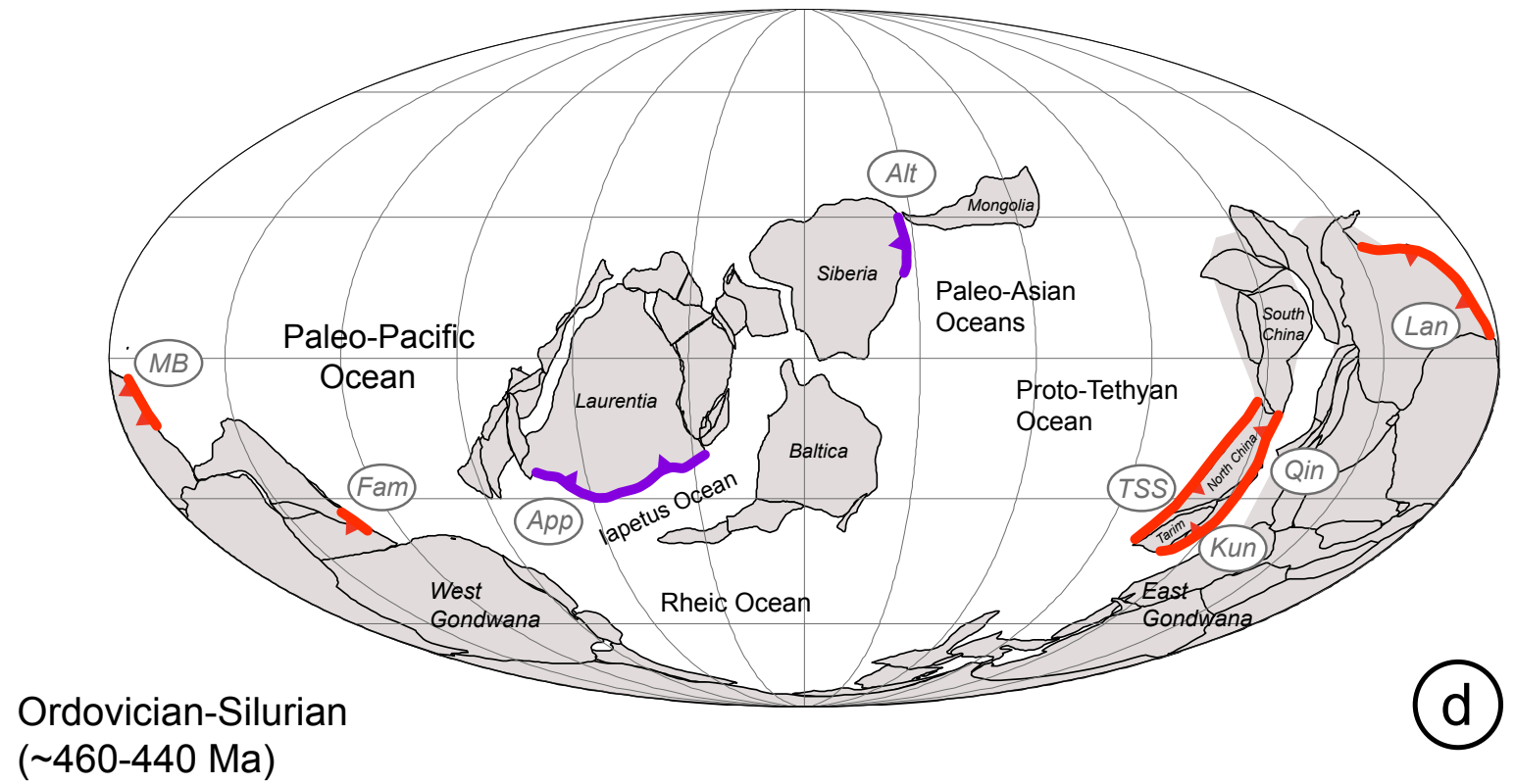

Central Meridian: $0^{\circ}$

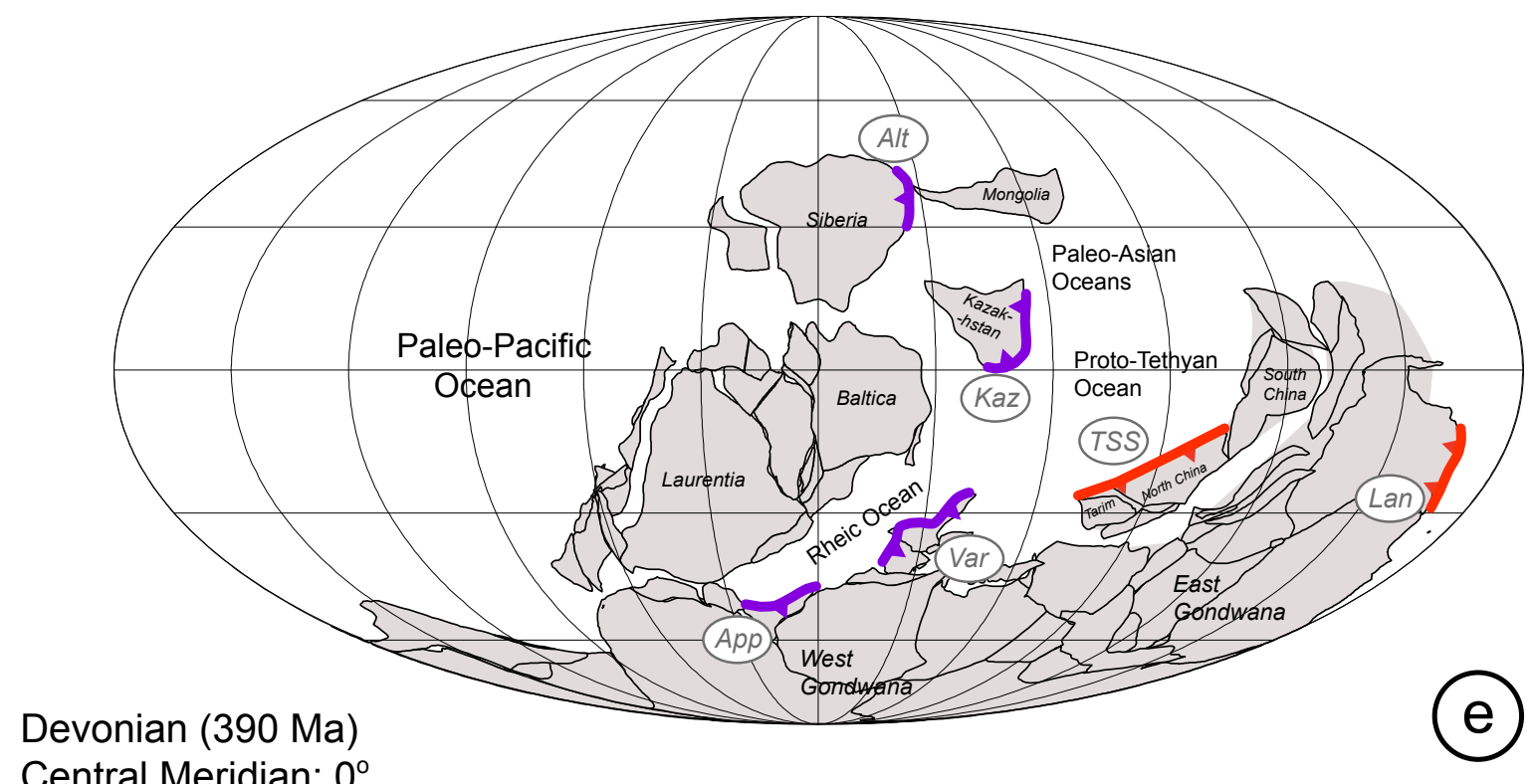

Central Meridian: $0^{\circ}$

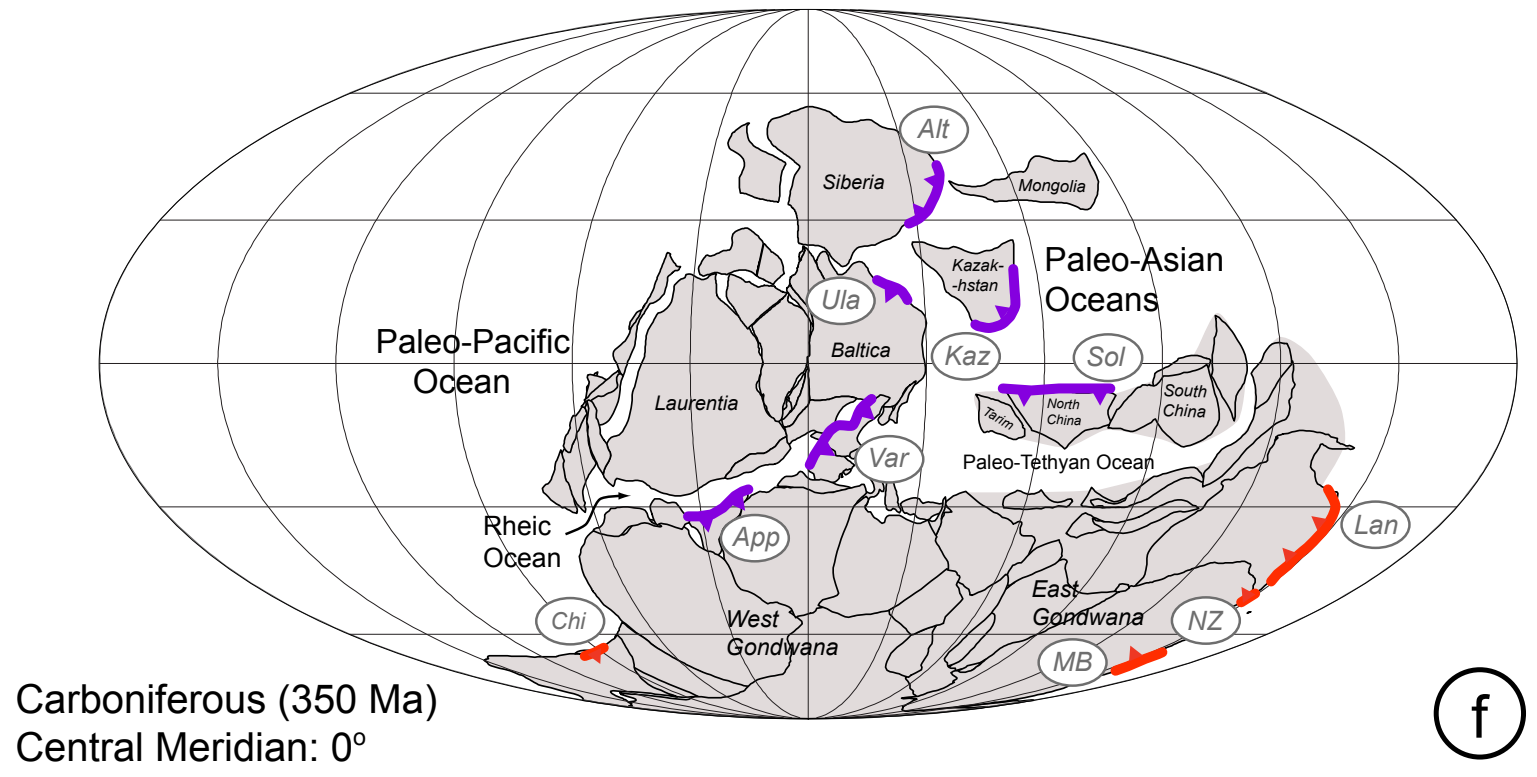

Fig. 3 d-f 


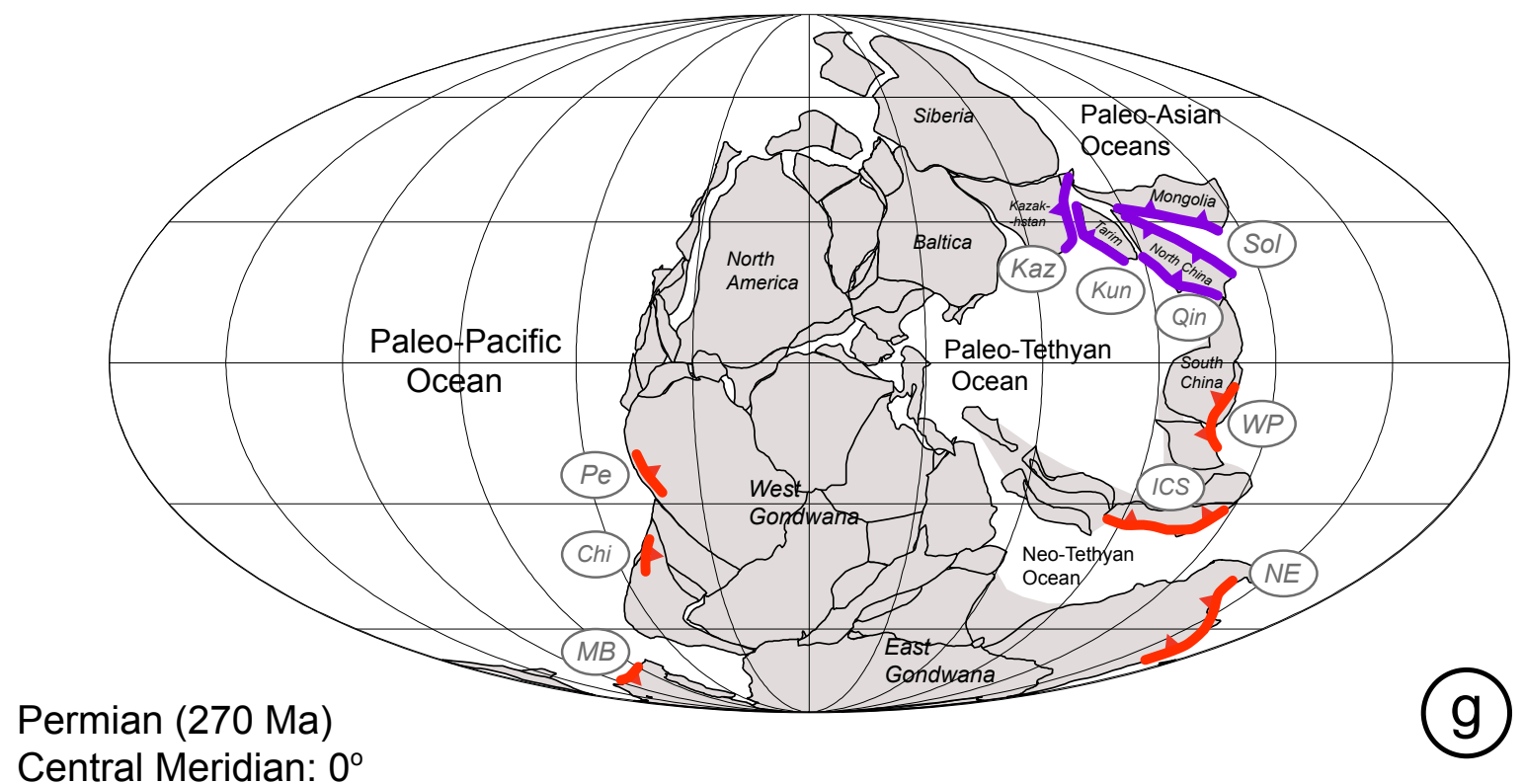

Central Meridian: $0^{\circ}$

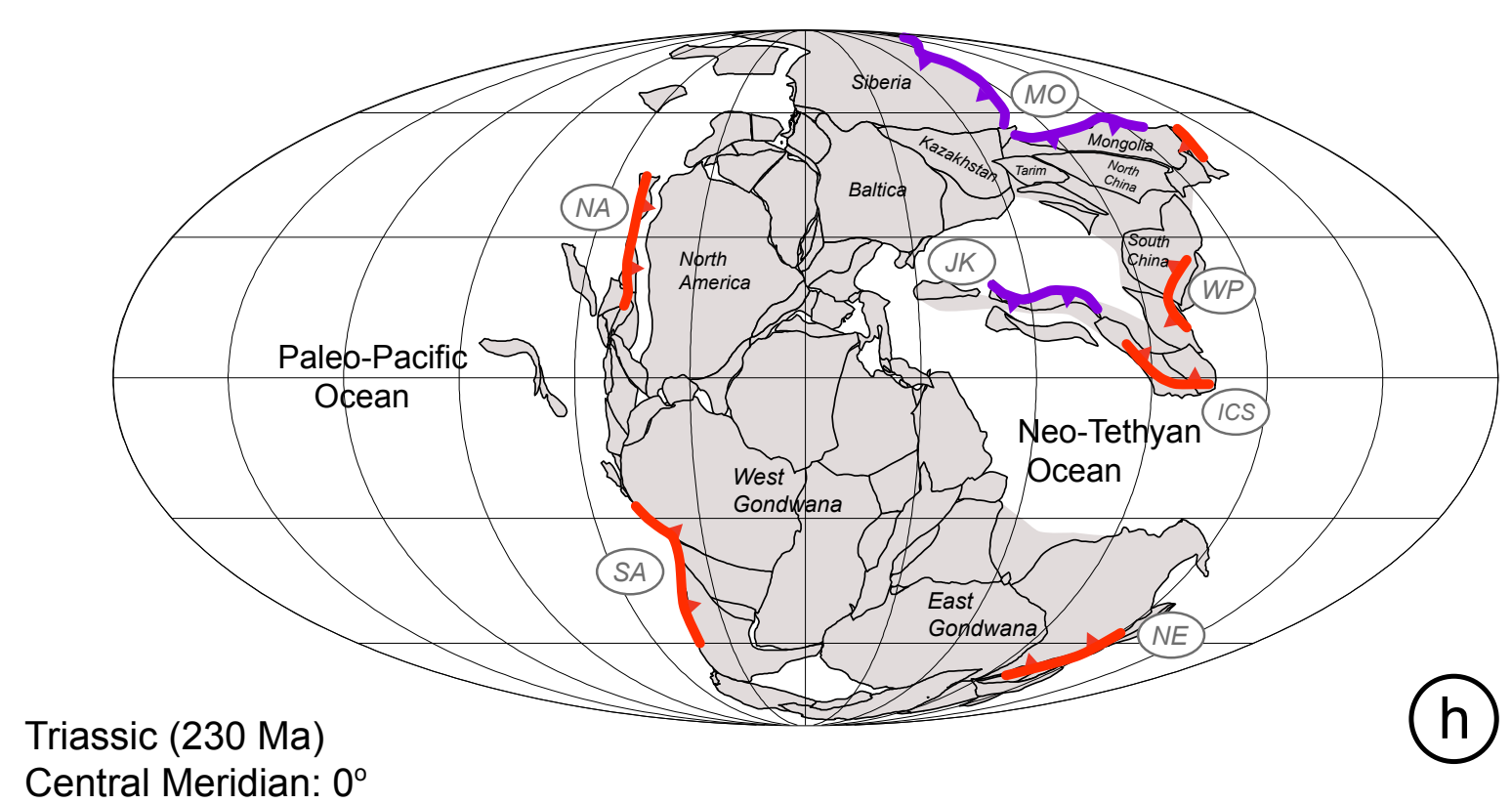

Central Meridian: $0^{\circ}$

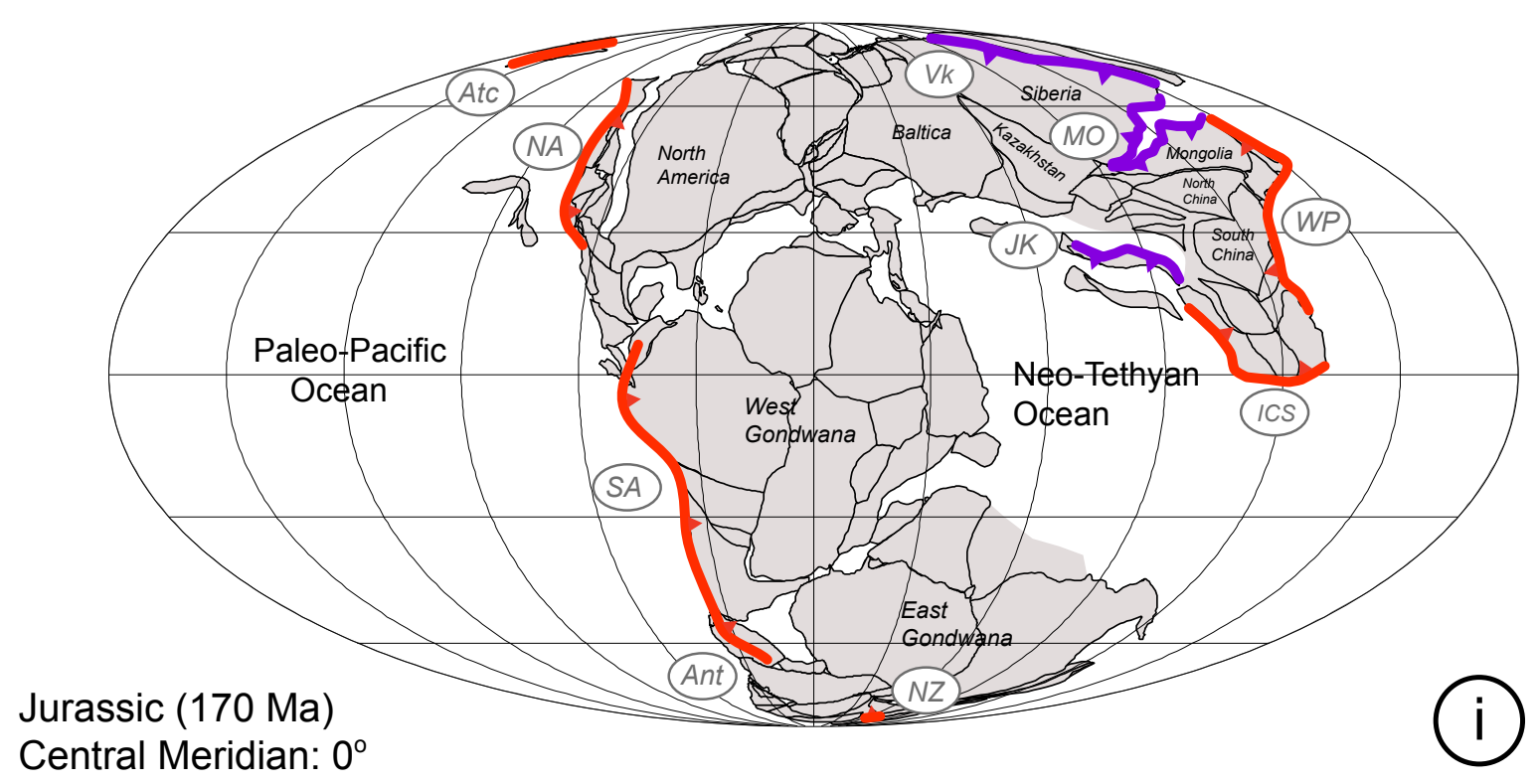

Fig. 3 g-i 

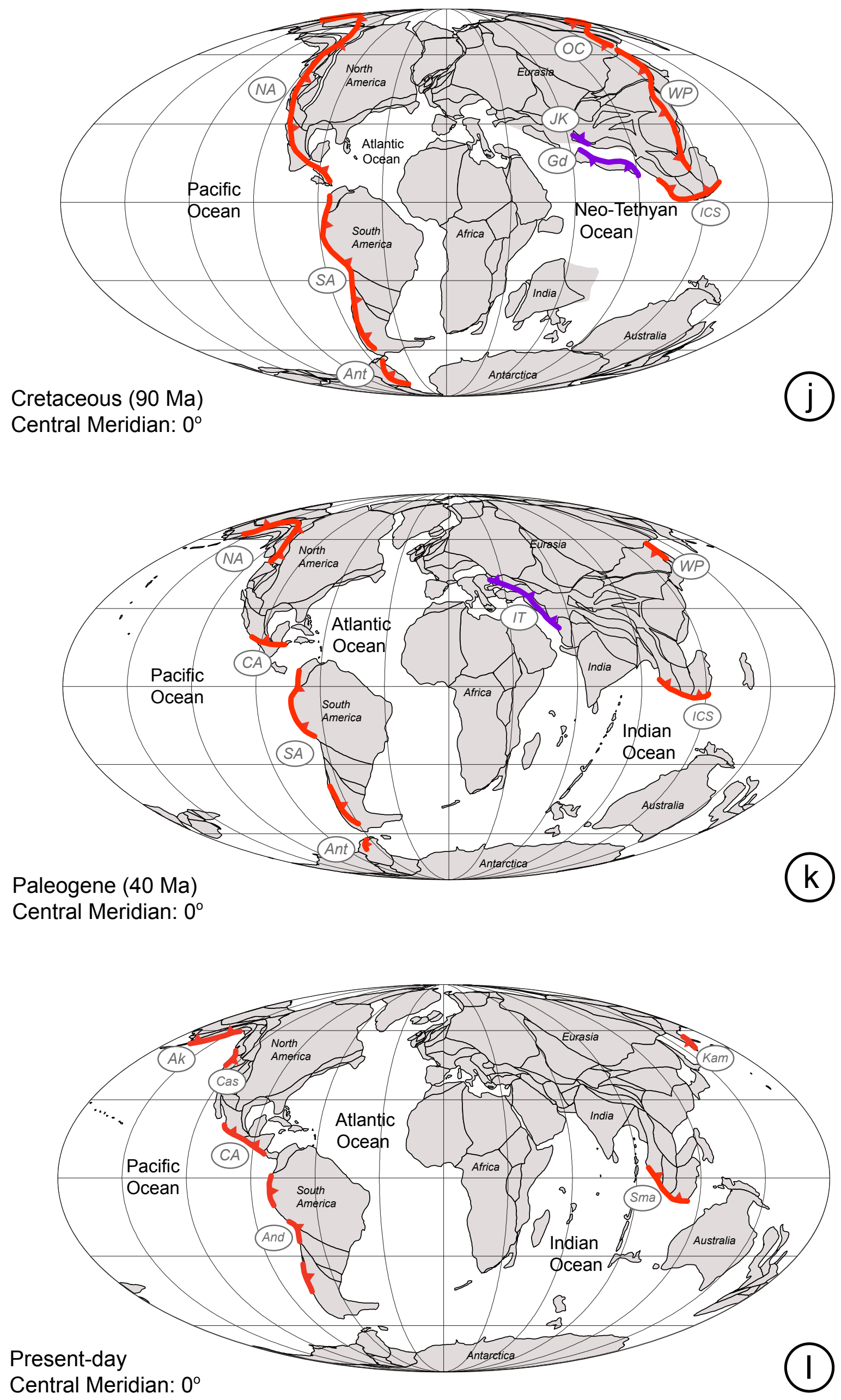

Fig. $3 j-I$ 


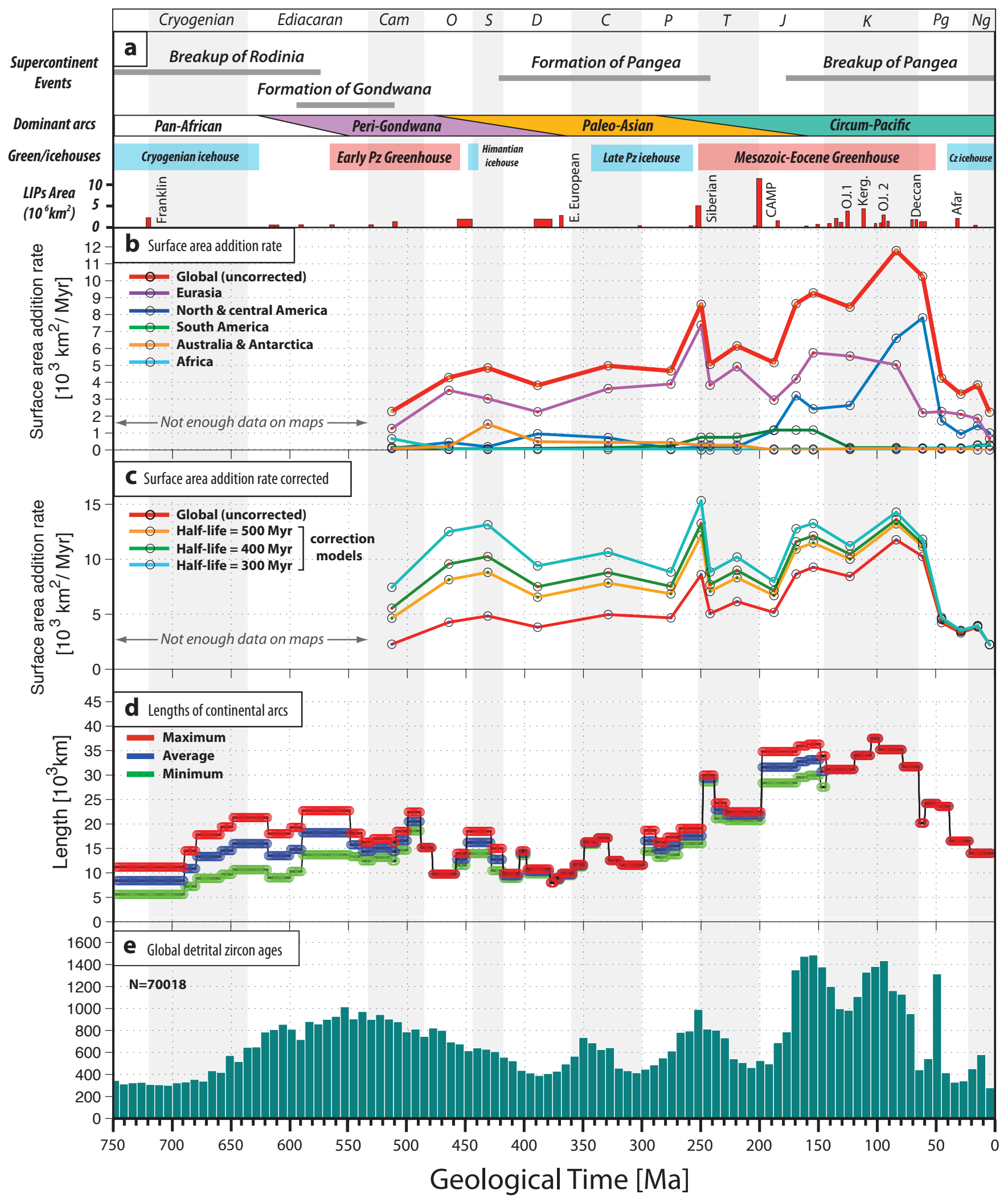

Fig. 4 